Original Article

\title{
FORMULATION AND EVALUATION OF CHLOROTHALIDONE LOADED MOUTH DISSOLVING FILM-A BIOAVAILABILITY ENHANCEMENT APPROACH USING MULTILEVEL CATEGORIC DESIGN
}

\author{
SHUBHAM BIYANI ${ }^{*}{ }^{*}$, SARANG MALGIRWAR ${ }^{1}$, RAJESHWAR KSHIRSAGAR ${ }^{1}$, SAGAR KOTHAWADE ${ }^{2}$ \\ ${ }^{1}$ School of Pharmacy, S. R. T. M. University, Nanded (MH), Vishnupuri 431606, India, ${ }^{2}$ Sinhgad Institute of Pharmacy, Pune (MH), Narhe \\ 411041 India \\ Email: sbiyani188@gmail.com
}

Received: 13 Oct 2019, Revised and Accepted: 22 Jan 2020

\begin{abstract}
Objective: The intension of the present study includes fabrication and optimization of mouth dissolving film loaded with Chlorothalidone by solvent evaporation techniques using two components and their three levels as multilevel Categoric design.

Methods: Major problem associated with the development of film loaded with BCS class II drug is to increase its solubility. Here the Chlorothalidone solubility achieved by co-solvents, such as methanol. After dissolving the drug in co-solvent, this drug solution is poured into an aqueous dispersion of Hydroxypropyl Methylcellulose E5 (HPMC E5) and Polyethylene glycol 400 (PEG 400). The two independent variables selected are factor A (concentration of HPMC E5) and factor B (concentration of PEG 400) was selected on the basis of preliminary trials. The percentage drug release (R1), Disintegration time in sec (R2) and folding endurance (R3) were selected as dependent variables. Here HPMC E5 used as a film former, PEG 400 as plasticizer, mannitol as bulking agent, Sodium starch glycolate as a disintegrating agent, tween 80 as the surfactant, tartaric acid as saliva stimulating agent, sodium saccharin as a sweetener and orange flavour etc. These fabricated films were evaluated for physicochemical properties,
\end{abstract} disintegration time and In vitro drug release study.

Results: The formulation F6 has more favorable responses as per multilevel categoric design is \% drug release about $98.95 \%$, average disintegration time about 24.33 second and folding endurance is 117. Thus formulation F6 was preferred as an optimized formulation.

Conclusion: The present formulation delivers medicament accurately with good therapeutic efficiency by oral administration, this mouth dissolving films having a rapid onset of action than conventional tablet formulations.

Keywords: Mouth dissolving film, Solvent evaporation techniques, Chlorothalidone, HPMC E5, Multilevel categoric designs, Design expert ${ }^{\circledR} 12$ software etc

(C) 2020 The Authors. Published by Innovare Academic Sciences Pvt Ltd. This is an open-access article under the CC BY license (http://creativecommons.org/licenses/by/4.0/) DOI: http://dx.doi.org/10.22159/ijpps.2020v12i3.36067. Journal homepage: https://innovareacademics.in/journals/index.php/ijpps

\section{INTRODUCTION}

Around all drug delivery systems, drug administration by the oral route is being considered more suitable. Various fast disintegrating drug delivery systems developed instead of capsules, tablet and syrups for the patient who having struggled in swallowing. Mouth dissolving film is preferable path to increase patient compliance [1].

Mouth dissolving film becomes a trending drug delivery system because of its various merits. On contact with saliva, it disintegrates within a minute seconds, without the demand of water, making them particularly appropriate for pediatric and geriatric patients. Drug from film directly reaches into systemic circulation, thus it avoids the first-pass effect [2]

Chlorothalidone is a phthalamide derivative of benzene sulphonamide, Thiazide diuretics are preferred pharmacological treatments for uncomplicated hypertension. Chlorothalidone is used in the present study and widely accepted for its excellent antihypertensive as well as anti-diuretic effect. It not only improves blood pressure but also swelling by preventing water absorption from the kidneys through inhibition of the $\mathrm{Na}^{+} / \mathrm{Cl}^{-}$symporter in the distal convoluted tubule cells in the kidney [3]

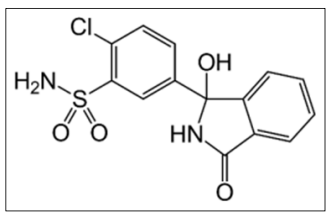

Fig. 1: Chlorthalidone
Multilevel categoric design generates trials that ultimately minimizes cost of an investigation. The outcomes of independent variables were studied on 9 different runs generated by the software. The rational of the present study is to enhance the bioavailability of Chlorothalidone by formulating as mouth dissolving film.

\section{MATERIALS AND METHODS}

\section{Materials}

Chlorothalidone (Gift sample of Aurobindo Pharma Ltd research Centre II, Hyderabad), HPMC E3, E5 (DOW chemicals), PEG 400 and Tween 80 LR (SDFCL Mumbai), Tartaric acid (Merck Chemicals Ltd., Mumbai), Mannitol (Roguette Freres), Sodium Saccharin, orange flavor (Burgoyne Burbidges and Co, Mumbai, India). All other reagents of analytical grade were used.

Methods

Drug excipients compatibility studies by Infrared spectroscopy (IR)

The IR absorption spectra of the pure drug and their physical mixture with accidents were recorded in the range of 4000-400 $\mathrm{cm}-1$ by using an IR spectrophotometer (PerkinElmer) [4] .

Preliminary trials for choosing a suitable polymer and plasticizer

Preliminary trials of formulation development were carried out using HPMC E3, E5 and sodium alginate etc. as film-forming agent with $2.5 \% \mathrm{w} / \mathrm{v}, 3.0 \% \mathrm{w} / \mathrm{v}$ and $3.5 \% \mathrm{w} / \mathrm{v}$ etc. From that sodium, alginate film was easily prone to breaking whereas HPMC E3 shows thin film formation. HPMC E5 has good film-forming property, 
satisfied disintegration time and good folding-endurance. In a preliminary feasibility study amount, less than $0.4 \% \mathrm{w} / \mathrm{v}$ of PEG 400 shows poor flexibility, whereas above $0.8 \% \mathrm{w} / \mathrm{v}$ shows sticky appearance. So that further formulation development was carried out between $0.4 \% \mathrm{w} / \mathrm{v}$ to $0.8 \% \mathrm{w} / \mathrm{v}$.

\section{Formulation of drug-loaded oral film}

Films were prepared as per the formula given in table 1 . Solvent casting method was used for the preparation of films using polymers (HPMC E5). Initially, the polymer was weighed accurately and dissolved in half the amount of water and mixed on a magnetic stirrer. The drug was weighed and dissolved in $1 \mathrm{ml}$ of methanol. Tartaric acid and sodium saccharin were both dissolved in the remaining amount of water. This solution was added to the polymeric solution and stirred well using a magnetic stirrer to obtain a homogeneous solution, followed by the addition of PEG 400 as a plasticizer and orange flavor. This solution was allowed to stand for $30 \mathrm{~min}$ for de-aeration of the solution. The solution was then cast in a petri dish and kept in a hot air oven for $8-10 \mathrm{~h}$ at $50{ }^{\circ} \mathrm{C}$. After drying, films were removed. Thus the obtained large film was cut into $3 \times 3 \mathrm{~cm}^{2}$. The film was stored in a butter paper covered with aluminum foil and stored in a desiccator.

Formulation of polymeric mouth dissolving film of chlorothalidone using a multilevel categoric design by design expert $^{\circledR} 12$ software

In order to optimize the independent variable, factor $\mathrm{A}$ (concentration of HPMC E5) and factor B (concentration of PEG 400) was selected for further development. These variables were taken at three different levels, i.e. lower, medium and higher level. Those variables were stipulated on the basis of the preliminary feasibility study earlier to the design of experiments.

The dependent variables or response evaluated were \% drug release, disintegration time in second and folding endurance, etc. The total 9 trials were generated by Design-Expert ${ }^{\circledR} 12$ software; the experimental data were analyzed using analysis of variance (ANOVA) by fitting responses in the respective run [5].

Table 1: Composition of chlorothalidone loaded mouth dissolving films (F1-F9)

\begin{tabular}{|c|c|c|c|c|c|c|c|c|c|}
\hline Ingredients (mg) & F1 & F2 & F3 & F4 & F5 & F6 & F7 & F8 & F9 \\
\hline Chlorothalidone & 98.38 & 98.38 & 98.38 & 98.38 & 98.38 & 98.38 & 98.38 & 98.38 & 98.38 \\
\hline Mannitol & 15 & 15 & 15 & 15 & 15 & 15 & 15 & 15 & 15 \\
\hline HPMC E5 & 250 & 250 & 250 & 300 & 300 & 300 & 350 & 350 & 350 \\
\hline SSG & 10 & 10 & 10 & 10 & 10 & 10 & 10 & 10 & 10 \\
\hline PEG 400 & 40 & 60 & 80 & 40 & 60 & 80 & 40 & 60 & 80 \\
\hline Sod. Saccharin & 10 & 10 & 10 & 10 & 10 & 10 & 10 & 10 & 10 \\
\hline Tartaric acid & 10 & 10 & 10 & 10 & 10 & 10 & 10 & 10 & 10 \\
\hline Orange flavour & Qs & Qs & Qs & Qs & Qs & Qs & Qs & Qs & Qs \\
\hline Water (ml) & $9 \mathrm{ml}$ & $9 \mathrm{ml}$ & $9 \mathrm{ml}$ & $9 \mathrm{ml}$ & $9 \mathrm{ml}$ & $9 \mathrm{ml}$ & $9 \mathrm{ml}$ & $9 \mathrm{ml}$ & $9 \mathrm{ml}$ \\
\hline Methanol & $1 \mathrm{ml}$ & $1 \mathrm{ml}$ & $1 \mathrm{ml}$ & $1 \mathrm{ml}$ & $1 \mathrm{ml}$ & $1 \mathrm{ml}$ & $1 \mathrm{ml}$ & $1 \mathrm{ml}$ & $1 \mathrm{ml}$ \\
\hline
\end{tabular}

\section{Dose calculation of the amount of drug per batch}

Dose of drug per film $=12.5 \mathrm{mg}$

An area of one film $=9 \mathrm{~cm}^{2}$

Area of petri plate $=70.84 \mathrm{~cm}^{2}$

Drug to be added per batch

$$
=(\text { Dose of drug per film } \times \text { Area of petri plate })
$$$$
\div \text { Area of one film }
$$

$=(12.5 \times 70.84) / 9=98.38 \mathrm{mg}$.

\section{Standard calibration curve of chlorothalidone}

$100 \mathrm{mg}$ of Chlorothalidone was dissolved in $10 \mathrm{ml}$ of $6.8 \mathrm{pH}$ phosphate buffer and volume was made up to $100 \mathrm{ml}$ with the $6.8 \mathrm{pH}$ phosphate buffer $(1000 \mu \mathrm{g} / \mathrm{ml}) .10 \mathrm{ml}$ of the above solution was diluted up to 100 $\mathrm{ml}$ with $6.8 \mathrm{pH}$ phosphate buffer $(100 \mu \mathrm{g} / \mathrm{ml})$. Then by serial dilution solutions with concentrations $5 \mu \mathrm{g} / \mathrm{ml}, 10 \mu \mathrm{g} / \mathrm{ml}, 15 \mu \mathrm{g} / \mathrm{ml}, 20 \mu \mathrm{g} / \mathrm{ml}$, $25 \mu \mathrm{g} / \mathrm{ml}$ and $30 \mu \mathrm{g} / \mathrm{ml}$ were prepared. Absorbance was measured on a Shimadzu 1800 Double Beam Spectrophotometer in the range of 200 to $400 \mathrm{~nm}$. Finally, a spectrum and wavelength of maximum absorption were recorded [6].

\section{Evaluation of chlorothalidone loaded mouth dissolving film}

\section{Appearance}

Formulated mouth dissolving films were assessed for their appearances either they are transparent or opaque by visual inspection or surface texture was assessed by contact or feel of the film [7].

\section{Weight variation}

The individual weight each of 10 films of $3 \times 3 \mathrm{~cm}^{2}$ for each formulation on an electronic weighing balance. The average weight was calculated [8].

\section{Thickness}

The average thickness of the mouth dissolving film was determined by using digital Vernier Calliper (Digimatic, Mitutoyo, Japan) with a least count of $0.01 \mathrm{~mm}$. The thickness was determined at five different places of the film and the average was taken and the standard deviation was calculated [9].

\section{Surface pH}

The surface $\mathrm{pH}$ was determined by placing one mouth dissolving film in a glass vial, adding $1 \mathrm{ml}$ of distilled water and wait for 30 Sec. The $\mathrm{pH}$ value obtained by bringing electrodes of $\mathrm{pH}$ meter (Lab, India) in contact with the moistened surface of the film. All measurements were performed in triplicate. It is essential that the strip should have an almost uniform $\mathrm{pH}$ value [10].

\section{Folding endurance}

It was determined by repeatedly collapsing the film of uniform cross-sectional area and thickness until it breaks. The number of times film was folded without breaking computed as the folding endurance value. This test ensures the tensile strength of the film. The number of times the film could be folded at the same place without breaking/cracking gave the value of folding endurance [11].

\section{Percent elongation}

At the point when stress is applied to the film sample stretches and is alluded to as a strain. Strain is basically the deformation of the film divided by the original dimension of the film. Generally, the flexibility of the film increases as the plasticizer concentration increases. Percentage elongation was calculated by measuring the increase in the length of the film after tensile strength measurement by using the following formula [12]. At the point when stress is applied to the film sample stretches and is alluded to as a strain.

Percentage Elongation $=[\mathrm{L}-\mathrm{L} 0] \times 100 \div \mathrm{L} 0$

Where $\mathrm{L}=$ Final length

L0 = initial length

\section{Percentage of moisture loss}

The percent moisture loss was evaluated by setting the prepared film in desiccators containing anhydrous calcium chloride. 
Following three days, the film was taken and reweighed. The percent moisture loss calculated was determined to utilize the following formula [13].

$$
\% \text { Moisture loss }=\frac{\text { Initial weight }}{\text { Initial weight }- \text { Final weight }} \times 100
$$

\section{Drug content}

A film of size $3 \times 3 \mathrm{~cm}^{2}$ is cut and put in $100 \mathrm{ml}$ of the volumetric flask containing solvent. This is then shaken in a mechanical shaker for 1 hour to get a homogeneous solution and filtered. The drug is determined spectroscopically after appropriate dilution. Chlorthalidone concentrations were assayed spectrophotometrically at $275.8 \mathrm{~nm}$ [14].

\section{In vitro dissolution study}

The dissolution test was accomplished using to USP type I Basket apparatus (Electrolab Dissolution tester, EDT-08Lx). The dissolution medium was $900 \mathrm{ml}$ of $6.8 \mathrm{pH}$ phosphate buffer, maintained at $37 \pm 10^{\circ} \mathrm{C}$ and stirred at $75 \mathrm{RPM}$. Each square cut film sample $(3 \mathrm{~cm} \times 3 \mathrm{~cm}$ ) was placed into the dissolution medium and appropriate aliquots were withdrawn at 3, 6, 9, 12 and 15 minute time intervals and again replaced with the same volume of dissolution media. The sample was filtered through Whatman filter paper for all the batches and analyzed spectrophotometrically at $275.8 \mathrm{~nm}$ (Model UV-1800 UV Visible spectrophotometer, Shimadzu, Japan). Sink conditions were maintained during the experiment. The dissolution test was performed in triplicate for each batch [15].

\section{In-vitro disintegration study}

The film size to be required for delivering a dose $\left(3 \times 3 \mathrm{~cm}^{2}\right)$ was placed on a glass Petri dish containing $10 \mathrm{ml}$ of $6.8 \mathrm{pH}$ phosphate buffer. The minimum time required for mouth dissolving film to break was noted as in vitro disintegration time [16].

\section{Stability study}

The stability study of the optimized formulation was carried out by storage conditions specified by ICH known as ICH guidelines. The single film wrapped in butter paper followed by packing in Aluminium foil and placed in accelerated stability conditions at $40 \pm 2{ }^{\circ} \mathrm{C}$ and $75 \pm 5 \% \mathrm{RH}$ for the period of $6 \mathrm{mo}$. Samples were taken at regular intervals and analyzed for folding endurance, drug content and \% drug release [17].

\section{RESULTS AND DISCUSSION}

Drug excipients compatibility study by infrared spectroscopy (IR)

IR spectrum of Chlorothalidone and physical mixture with excipients was recorded and it was found in accordance with the reported peaks. It is shown in below fig. (fig. 2 and 3). The IR spectra of Chlorothalidone comply with its chemical structure and show peaks for principal groups. The structural assignments for the characteristic absorption bands are listed in the following table 2.

In physical mixtures of Chlorothalidone and excipients, there was neither masking of single characteristic peak nor the existence of an additional peak in drug spectra. The overall correlation in the two spectra was 0.9999. So it was concluded that all excipients were compatible with each other.

Optimization of the selected independent variable by designexpert $^{\circledR} 12$ software

In a preliminary feasibility study, films were prepared with different polymers like HPMC (E3, E5) and sodium alginate. Finally, from these trials made and results obtained, HPMC E5 and PEG 400 were selected with different levels for further formulation development. The polymer HPMC E5 and plasticizer PEG 400 were taken at three different level, i.e. lower, medium and higher level. Thus, total 9 trails were obtained by Design-Expert ${ }^{\circledR 12}$ software and the dependent variables or response evaluated were \% drug release in $15 \mathrm{~min}$, disintegration time (second) and folding endurance (number of folds) are shown in table 3.

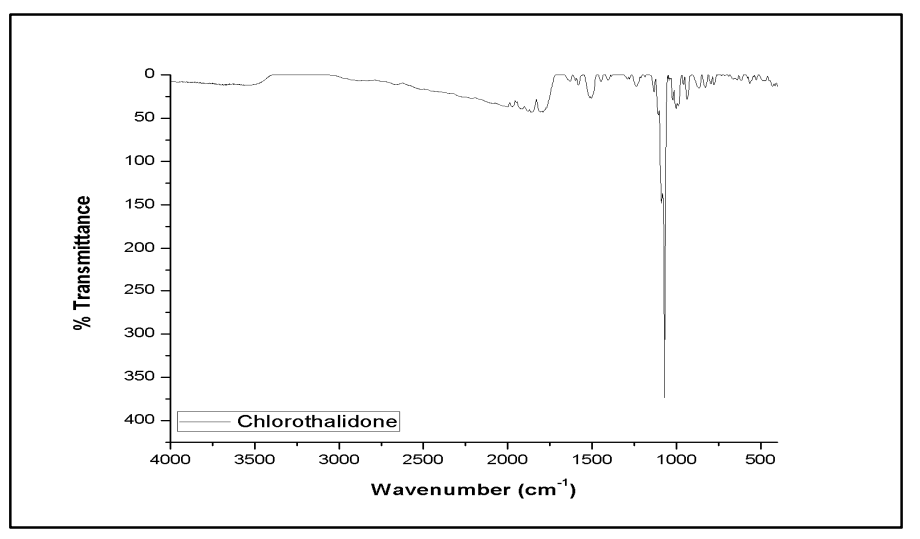

Fig. 2: IR spectrum of pure chlorthalidone

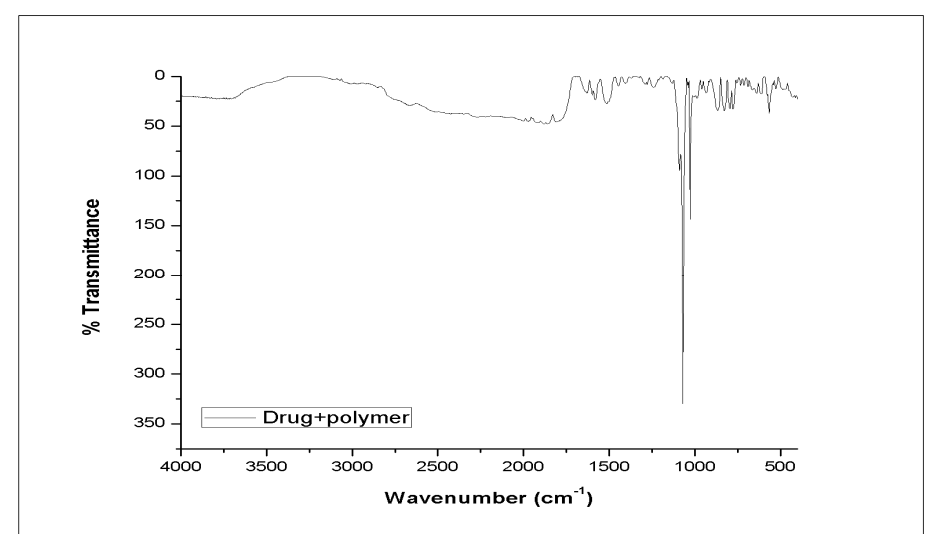

Fig. 3: IR Spectrum of chlorothalidone and excipients 
Table 2: Infrared spectral assignment for chlorothalidone

\begin{tabular}{lllll}
\hline S. No. & Functional group & Reported frequency $\left(\mathbf{c m}^{-1}\right)$ & Frequency for drug (cm-1) & $\begin{array}{c}\text { Frequency physical mixture of drug and } \\
\text { excipients }\left(\mathbf{c m}^{-1}\right)\end{array}$ \\
\hline 1 & C=O (S) & $1630-1980$ & 1828.59 & 1828.28 \\
2 & Primary NH (S) & $3100-3500$ & 3361.92 & 3361.92 \\
3 & SO2 (S) & $1000-1100$ & 1039.63 & 1037.34 \\
4 & OH (S) & $3200-3400$ & 3255.84 & 3253.55 \\
\hline
\end{tabular}

Table 3: Optimization parameters of chlorothalidone loaded mouth dissolving films

\begin{tabular}{|c|c|c|c|c|c|}
\hline \multirow[t]{2}{*}{ Run } & \multicolumn{2}{|c|}{ Independent variables } & \multicolumn{3}{|l|}{ Dependent variables } \\
\hline & $\begin{array}{l}\text { Factor } 1 \\
\text { HPMC E5 (mg) }\end{array}$ & $\begin{array}{l}\text { Factor } 2 \text { PEG } 400 \\
(\mathrm{mg})\end{array}$ & \% Drug release in 15 Min & $\begin{array}{l}\text { Disintegration time } \\
\text { (Sec) }\end{array}$ & $\begin{array}{l}\text { Folding endurance } \\
\text { (Folds) }\end{array}$ \\
\hline F1 & 250 & 40 & 99.12 & 19.22 & 49 \\
\hline $\mathrm{F} 2$ & 250 & 60 & 99.56 & 17.87 & 64 \\
\hline F3 & 250 & 80 & 99.93 & 16.62 & 79 \\
\hline F4 & 300 & 40 & 98.17 & 31.12 & 96 \\
\hline F5 & 300 & 60 & 98.48 & 27.84 & 104 \\
\hline F6 & 300 & 80 & 98.95 & 24.33 & 117 \\
\hline F7 & 350 & 40 & 89.46 & 46.16 & 125 \\
\hline F8 & 350 & 60 & 91.87 & 39.41 & 131 \\
\hline F9 & 350 & 80 & 94.26 & 35.45 & 140 \\
\hline
\end{tabular}
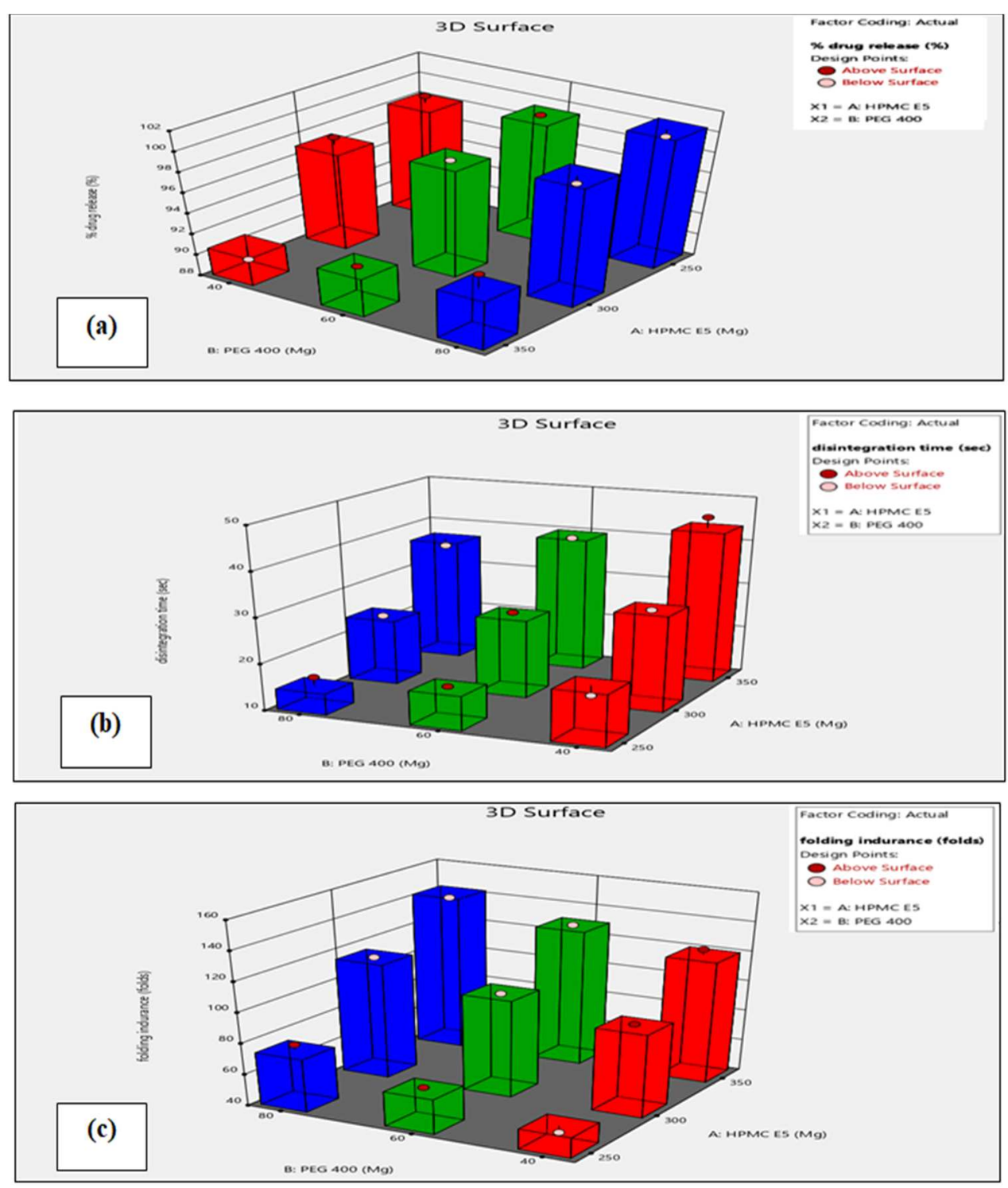

Fig. 4: 3 D surface plots (a-c) showing the effect of the selected independent variable on dependent variable viz. \% Drug release (R1), disintegration time (R2) and folding endurance (R3) 
Table 4: ANOVA for chlorothalidone mouth dissolving film from multilevel categoric design

\begin{tabular}{|c|c|c|c|c|c|}
\hline Source & d.f. & Sum square & Mean square & Fvalue & Pvalue \\
\hline \multicolumn{6}{|c|}{ \% Drug release in 15 Min (Response 1 ) } \\
\hline A-HPMC E5 & 2 & 104.38 & 52.19 & 39.01 & 0.0024 \\
\hline B-PEG 400 & 2 & 6.81 & 3.40 & 2.54 & 0.1938 \\
\hline Model & 4 & 111.18 & 27.80 & 20.77 & 0.0061 \\
\hline \multicolumn{6}{|c|}{ Disintegration time Sec (Response 2) } \\
\hline A-HPMC E5 & 2 & 758.80 & 379.40 & 87.40 & 0.0005 \\
\hline B-PEG 400 & 2 & 67.73 & 33.86 & 7.80 & 0.0416 \\
\hline Model & 4 & 826.52 & 206.63 & 47.60 & 0.0013 \\
\hline \multicolumn{6}{|c|}{ Folding endurance (Response 3 ) } \\
\hline A-HPMC E5 & 2 & 7053.56 & 3526.78 & 238.65 & 0.0001 \\
\hline B-PEG 400 & 2 & 729.56 & 364.78 & 24.68 & 0.0056 \\
\hline Model & 4 & 7783.11 & 1945.78 & 131.67 & 0.0002 \\
\hline
\end{tabular}

Numerical optimization

Table 5: Constraints for selected independent variables

\begin{tabular}{|c|c|c|c|c|c|c|}
\hline Name & Goal & Lower limit & Upper limit & Lower weight & Upper weight & Importance \\
\hline A: HPMC E5 & is in range & 250 & 350 & 1 & 1 & 3 \\
\hline B: PEG 400 & is in range & 40 & 80 & 1 & 1 & 3 \\
\hline Dissolution in 15 Min & Maximize & 89.46 & 99.93 & 1 & 1 & 5 \\
\hline Disintegration time (Sec) & Minimize & 16.62 & 46.16 & 1 & 1 & 5 \\
\hline Folding endurance (Folds) & Maximize & 49 & 140 & 1 & 1 & 5 \\
\hline
\end{tabular}

Table 6: Different solutions for 9 combinations

\begin{tabular}{lllllll}
\hline Number & HPMC E5 & PEG 400 & Dissolution in 15 min & Disintegration time & Folding endurance & Desirability \\
\hline 1 & 300 & 80 & 99.602 & 24.561 & 117.111 \\
2 & 300 & 60 & 98.526 & 27.468 & 104.778 \\
3 & 250 & 80 & 100.606 & 14.701 & 75.444 \\
4 & 300 & 40 & 97.472 & 31.261 & 95.111 & 0.695 \\
5 & 250 & 60 & 99.529 & 17.608 & 0.662 \\
6 & 350 & 80 & 92.932 & 91.856 & 37.138 & 143.444 \\
7 & 350 & 60 & 98.476 & 21.0401 & 0.580 & 0.524 \\
8 & 250 & 40 & 90.802 & 43.838 & 0.466 \\
9 & 350 & 40 & & & 0.350 \\
\hline
\end{tabular}

Table 7: Regression analysis of response $\mathrm{R} 1, \mathrm{R} 2$ and $\mathrm{R} 3$

\begin{tabular}{|c|c|c|c|c|c|}
\hline Factorial model & $\mathbf{R}^{2}$ & Adjusted $\mathrm{R}^{2}$ & Predicted $\mathrm{R}^{2}$ & SD & $\% \mathrm{CV}$ \\
\hline R1 \% Drug release in $15 \mathrm{~min}$ & 0.9541 & 0.9082 & 0.7675 & 1.16 & 1.20 \\
\hline R2 Disintegration time (sec) & 0.9794 & 0.9588 & 0.8958 & 2.08 & 7.27 \\
\hline R3 folding endurance (folds) & 0.9925 & 0.9849 & 0.9618 & 3.84 & 3.82 \\
\hline
\end{tabular}

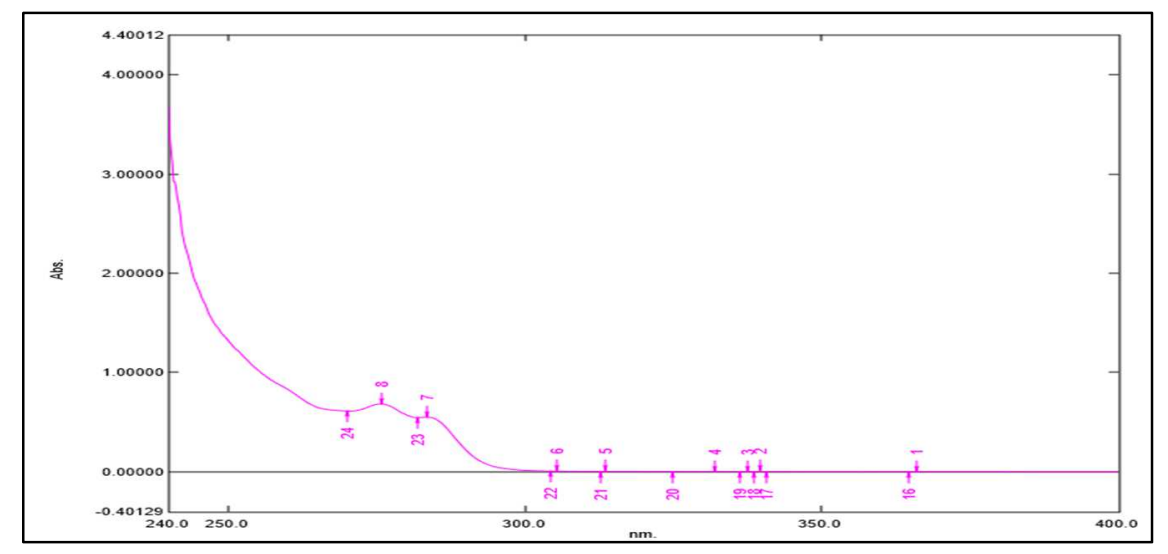

Fig. 5: UV spectrum of chlorthalidone

\section{Determination of $\lambda$ max}

A concentration of $30 \mu \mathrm{g} / \mathrm{ml}$ was prepared from standard Chlorothalidone solution and scanned by a UV-visible spectrophotometer in the range of 200-400 nm using $6.8 \mathrm{pH}$ phosphate buffer as blank then the maximum wavelength $(\lambda$-max $)$ was determined (fig. 5).
Standard calibration curve of chlorthalidone in $6.8 \mathrm{pH}$ phosphate buffer

Chlorthalidone showed maximum absorption at wavelength 275.8 $\mathrm{nm}$ in $6.8 \mathrm{pH}$ phosphate buffer. A standard curve was plotted by taking absorption of diluted stock solutions $(5,10,15,20,25$ and 30 $\mu \mathrm{g} / \mathrm{ml}$ ) at wavelength $275.8 \mathrm{~nm}$ [18]. 
Table 8: Standard calibration curve of chlorothalidone in $6.8 \mathrm{pH}$ phosphate buffer

\begin{tabular}{lll}
\hline S. No. & Concentration $(\boldsymbol{\mu g} / \mathbf{m l})$ & Absorbance at 275.8 $\mathbf{~ n m}$ \\
\hline 1 & 5 & 0.0598 \\
2 & 10 & 0.1507 \\
3 & 15 & 0.2102 \\
4 & 20 & 0.2931 \\
5 & 25 & 0.3675 \\
6 & 30 & 0.4178 \\
\hline
\end{tabular}

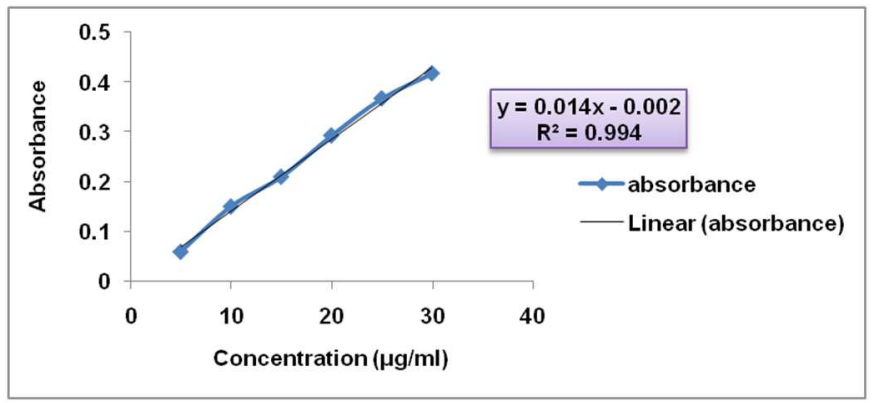

Fig. 6: Calibration curve of chlorothalidone in $6.8 \mathrm{pH}$ phosphate buffer

\section{Preparation and physical characterization of chlorothalidone} mouth dissolving film

Preliminary feasibility trails were prepared with different polymers like HPMC (E3, E5) and sodium alginate. Finally, from these trials made and results obtained, HPMC E5 and PEG 400 were selected with different levels for further formulation development.

\section{Evaluation of films}

\section{Appearance}

In preliminary trails, film from sodium alginate shows brittle nature, whereas HPMC E3 shows thin film-forming ability. Finally, the film prepared with HPMC E5 showed good film-forming property. Mouth dissolving films were visually evaluated, all films F1 to F9 shows good transparency, homogeneity and smooth appearance. All the formulations showed no change in the properties at the end of 6 the month time period [19].

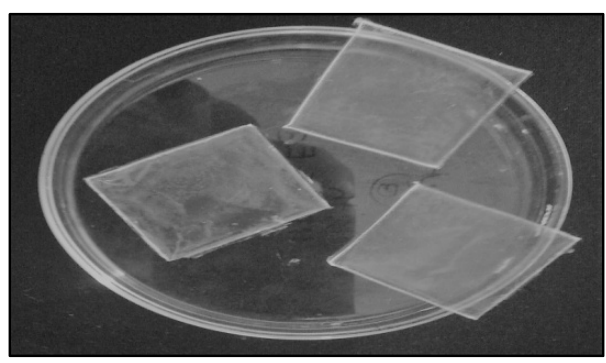

Fig. 7: Photograph of optimized formulation (F6) of mouth dissolving film

\section{Wt. variation}

The weight of mouth dissolving film was determined by using digital weighing balance and the average weight of all film (F1 to F9) was found to be in the range of $55-73 \mathrm{mg}$. Some films shows less than $5 \%$ variation in the weight, maybe due to lack of flat surface in petri plate or slant surface of hot air oven. Form a result, it was observed that the increase in polymer-plasticizer ratio weight of films also increased [8].

\section{Thickness}

The thickness of the mouth dissolving films was measured using digital Vernier caliper and the average thickness of all Fast dissolving film was found in between $0.153-0.349 \mathrm{~mm}(\mathrm{n}=3)$. All films show a standard deviation of average thickness in the range $0-5 \%$ that may be due to good positioning during the solvent evaporation process [20].

\section{Surface pH}

The surface $\mathrm{pH}$ was noted by $\mathrm{pH}$ meter near the surface of the fastdissolving film and allowing equilibrating for $30 \mathrm{Sec}$ and the surface $\mathrm{pH}$ of all fast dissolving film was found to in between 6.59-6.89 $\mathrm{pH}$ $(\mathrm{n}=3)$. All batches show $\mathrm{pH}$ towards a neutral range, which is evidence for the absence of oral mucosal irritation [10].

\section{Folding endurance}

The average folding endurance of all Fast dissolving films was ranging from 49-140. It was observed that folding endurance increases with increasing plasticizer concentration [11].

\section{Percentage elongation}

The average \% elongation for formulation $\mathrm{F} 1$ to $\mathrm{F} 9$ was found in the range of $10.79 \pm 0.32 \%$ to $19.23 \pm 0.68 \%$. Percentage elongation was decreased with increasing polymer concentration [12].

\section{Percentage of moisture loss}

The percentage of moisture loss of formulations F1 to F9 was estimated. The average \% moisture loss found in the range of $1.471 \pm 0.008 \%$ to $1.974 \pm 0.004 \%$. All formulation shows moisture within the limits that is evidence for the stability of the film against microbial growth [13].

\section{Drug content}

The percentage of drug content for all trails F1 to F9 was obtained in the range of $98.21 \pm 0.27 \%$ to $99.87 \pm 0.20 \%$. All films having drug content within the limits, therefore it can be concluded that mouth dissolving film will deliver an accurate dose of medicament [15].

\section{In vitro dissolution study}

In vitro dissolution investigation of Chlorothalidone loaded mouth dissolving film was carried out in $\mathrm{pH} 6.8$ phosphate buffer solution (shown in fig. 8). Drug release from F1 to F9 was more than $90 \%$ within $15 \mathrm{~min}$. It was observed that the drug release is slower with increasing polymer concentration [21].

\section{In-vitro disintegration study}

Mouth dissolving film with dimension $3 \times 3 \mathrm{~cm}^{2}$ size taken and disintegration time observed visually. Average disintegration times of three fast dissolving films were calculated. Disintegration time ranges from 16-46 seconds, which indicates the disintegration time of film obtained within a minute. As polymer concentration increases disintegration time also increases, but PEG 400 minimizes disintegration time [16]. 
Table 9: Formulation result from trails batches

\begin{tabular}{llllll}
\hline Run & $\begin{array}{l}\text { Weight (mg) } \\
\text { (n=3) }\end{array}$ & $\begin{array}{l}\text { Thickness (mm) } \\
(\mathbf{n = 3})\end{array}$ & $\begin{array}{l}\text { Surface pH } \\
\text { (n=3) }\end{array}$ & $\begin{array}{l}\text { \% Elongation } \\
\text { (n=3) }\end{array}$ & $\begin{array}{l}\text { \% Moisture loss } \\
(\mathbf{n = 3})\end{array}$ \\
\hline F1 & $55.12 \pm 0.076$ & $0.153 \pm 0.017$ & $6.81 \pm 0.88$ & $18.81 \pm 0.74$ & $1.794 \pm 0.001$ \\
F2 & $57.56 \pm 0.054$ & $0.162 \pm 0.027$ & $6.84 \pm 0.54$ & $19.23 \pm 0.68$ & $1.974 \pm 0.004$ \\
F3 & $59.98 \pm 0.015$ & $0.164 \pm 0.012$ & $6.89 \pm 0.15$ & $18.13 \pm 0.41$ & $1.663 \pm 0.001$ \\
F4 & $61.41 \pm 0.044$ & $0.241 \pm 0.021$ & $6.78 \pm 0.24$ & $14.27 \pm 0.33$ & $1.659 \pm 0.007$ \\
F5 & $63.87 \pm 0.037$ & $0.249 \pm 0.014$ & $6.92 \pm 0.37$ & $16.89 \pm 0.87$ & $1.513 \pm 0.004$ \\
F6 & $66.61 \pm 0.043$ & $0.253 \pm 0.03$ & $6.96 \pm 0.66$ & $14.72 \pm 0.57$ & $1.669 \pm 0.003$ \\
F7 & $67.76 \pm 0.028$ & $0.327 \pm 0.082$ & $6.59 \pm 0.69$ & $11.67 \pm 0.92$ & $1.539 \pm 0.002$ \\
F8 & $70.31 \pm 0.092$ & $0.349 \pm 0.038$ & $6.66 \pm 0.52$ & $10.79 \pm 0.32$ & $1.471 \pm 0.008$ \\
F9 & $72.84 \pm 0.019$ & $0.339 \pm 0.043$ & $6.81 \pm 0.13$ & $13.07 \pm 0.63$ & 99.59 \\
\hline
\end{tabular}

*All data are given in mean \pm SD

Table 10: In vitro drug release profiles of mouth dissolving film

\begin{tabular}{|c|c|c|c|c|c|}
\hline \multirow[t]{2}{*}{ Batches } & \multicolumn{5}{|c|}{ \% Drug release } \\
\hline & 3 Min & $6 \mathrm{Min}$ & 9 Min & $12 \mathrm{Min}$ & $15 \mathrm{Min}$ \\
\hline F1 & 16.12 & 44.23 & 69.27 & 84.64 & 99.12 \\
\hline $\mathrm{F} 2$ & 19.74 & 46.32 & 74.11 & 87.45 & 99.56 \\
\hline F3 & 21.46 & 49.22 & 79.41 & 91.37 & 99.93 \\
\hline F4 & 9.45 & 32.04 & 57.41 & 82.66 & 98.17 \\
\hline F5 & 11.25 & 37.44 & 61.23 & 86.74 & 98.48 \\
\hline F6 & 15.12 & 41.16 & 66.87 & 84.43 & 98.95 \\
\hline F7 & 5.46 & 19 & 50.41 & 71.22 & 89.46 \\
\hline F8 & 8.22 & 24 & 54.44 & 77.54 & 91.87 \\
\hline F9 & 10.49 & 29 & 62.96 & 81.41 & 94.26 \\
\hline
\end{tabular}

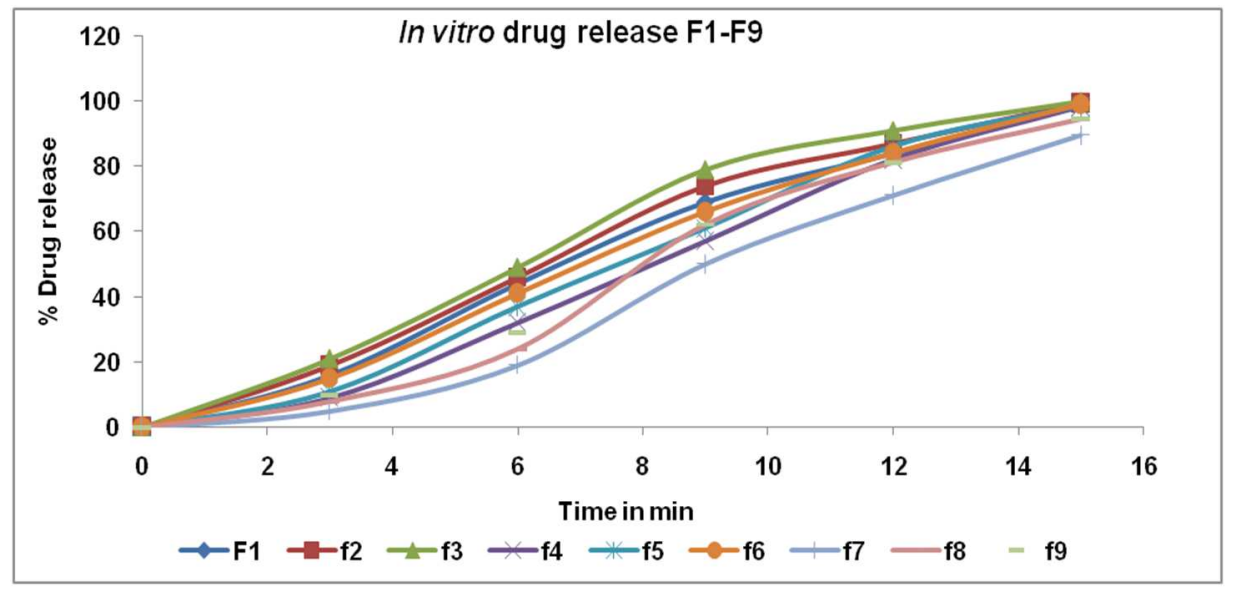

Fig. 8: Comparison of in vitro dissolution profile between F1 to F9

Table 12: Accelerated stability study of optimized trail F6

\begin{tabular}{|c|c|c|c|c|}
\hline \multirow[t]{2}{*}{ Parameter for study } & \multicolumn{4}{|c|}{ The maintained temperature at $40 \pm 2{ }^{\circ} \mathrm{C}$ and relative humidity $(\mathrm{RH})$ at $75 \% \pm 5 \% \mathrm{RH}$} \\
\hline & Initial & After1 mo & After 3 mo & After 6 mo \\
\hline$\%$ Drug release & 98.95 & 98.91 & 98.82 & 98.49 \\
\hline Drug content $(\%)(n=3)$ & $98.21 \pm 0.27$ & $98.71 \pm 0.41$ & $98.11 \pm 0.87$ & $98.49 \pm 0.62$ \\
\hline Folding endurance & 117 & 121 & 114 & 116 \\
\hline
\end{tabular}

*Data are given in mean $\pm \mathrm{SD}, \mathrm{n}=3$

\section{Stability study}

Optimized formulation (F6) do not show changes in appearance, folding endurance, drug content and In-vitro \% drug release after placing in the Accelerated Stability Studies. Hence the formulation (F6) was indicated to be stable [17].

\section{CONCLUSION}

Mouth dissolving films of Chlorothalidone were fabricated with HPMC E5 and PEG 400 by using the solvent evaporation technique.
All formulation shows a good drug release profile, drug content, folding endurance, disintegration time, $\mathrm{pH}$ and $\%$ elongation etc.

Among that formulation, F6 shows better drug release, disintegration time, folding endurance and found to be a good stable at accelerated stability condition specified by ICH.

So that F6 batch considered as optimized formulation. Hence mouth dissolving film of Chlorothalidone was found to be suitable for the management of edema and hypertension. 


\section{ACKNOWLEDGMENT}

The authors thank Aurobindo pharma Ltd. Research Centre II, Hyderabad, for providing Chlorothalidone drug as gift samples for this work. They are thanking to the school of physical science SRTMU Nanded for carrying out IR compatibility studies. They thank for providing required facilities to carry out this research work at the School of Pharmacy SRTM University Nanded, Maharashtra, India.

\section{FUNDING}

Nil

\section{AUTHORS CONTRIBUTIONS}

The authors of this research article share an equal contribution in all steps up to the approval of the final version.

\section{CONFLICT OF INTERESTS}

Authors have none conflict of interest

\section{REFERENCES}

1. Averineni RK, Sunderajan SG, Utalik S, Nayak U, Shavi $\mathrm{G}$, Armugam K, et al. Development of mucoadhesive buccal films for the treatment of oral sub-mucous fibrosis: a preliminary study. Pharm Dev Technol 2009;14:199-207.

2. Ashwin S, Vishal Y, Vinay G, Shree D. Fast disintegrating drug delivery system: a review. Int J Pharma Sci Res 2014;5:1859-73.

3. KD Tripathi. Essentials of medical pharmacology. $7^{\text {th }}$ ed. Jaypee Brothers Medical Publishers (P) Ltd; 2013. p. 558-60.

4. Aigner Z. Compatibility studies of aceclofenac with retard tablet excipients by means of thermal and FT-IR spectroscopic methods. J Therm Anal Calorim 2010;104:265-71.

5. Aiswarya G, Hussan Reza, Rajan RK. Development, evaluation, and optimization of flurbiprofen nanoemulsions gel using quality by design concept. Asian J Pharma 2015;9:35-43.

6. Mahfuza Maleque, Md Raquibul Hasan, Farhad Hossen, Sanjana Safi. Development and validation of a simple UV spectrophotometric method for the determination of levofloxacin both in bulk and marketed dosage formulations. J Pharma Anal 2012;2:454-7.

7. Pawar SV, Junagade MS. Formulation and evaluation of mouth dissolving film of risperidone. Int $\mathrm{J}$ Pharm Tech Res 2015;8:218-30.

8. Sudhir Maddela, Buchi N Nalluri. Development of zolmitriptan mouth dissolving films: formulation variables, mechanical properties, and in vitro drug release studies. Asian J Pharm Clin Res 2019;12:273-9.
9. Muhammad Bilal Hassan Mahboob, Tehseen Riaz, Muhammad Jamshaid, Irfan Bashir, Saqiba Zulfiqar. Oral films: a comprehensive review. Int Curr Pharma J 2016;5:111-9.

10. Alka Tomar, Kiran Sharma, Nitesh S Chauhan, Ashu Mittal, Umakant Bajaj. Formulation and evaluation of fast dissolving oral film of dicyclomine as a potential route of buccal delivery. Int J Drug Dev Res 2012;4:408-17.

11. Lakshmi PK, Malavika P, Vidya K. Formulation and evaluation of oral films of atomoxetine hydrochloride. Int Res J Pharm 2018;9:105-9.

12. Prudvi KN, G Prasad, B Vijay Kumar. Oral dissolving films of chlorpheniramine maleate. Int J Pharm Sci Res 2014;5:185973.

13. Pathan A, Mahesh KG, Neetesh KJ, Ankita D, Ankit A. Formulation and evaluation fast dissolving oral films of promethazine hydrochloride using a different surfactant. J Innovations Pharma Bio Sci 2016;3:74-84.

14. Kulkarni PK, Dixit M, Gunashekara K, Shahnawaz A, Kulkarni A, Singh MN. Formulation and evaluation of mouth dissolving film containing rofecoxib. Int Res J Pharma 2011;2:273-8.

15. Lakshmi PK, Malavika P, Vidya K. Formulation and evaluation of oral films of atomoxetine hydrochloride. Int Res J Pharm 2018;9:105-9.

16. Pravin Kumar Sharma, Pankaj Kumar Sharma, Gajanan N. Darwhekar, birendra shrivastava. development and evaluation of fast-dissolving oral film of poorly water-soluble drug felodipine. Asian J Pharm 2018;12:258-67.

17. Bala R, Pawar P, Khanna S, Arora S. Orally dissolving strips: a new approach to oral drug delivery system. Int J Pharm Investig 2013;3:67-76.

18. NG Raghavendra Rao, K Ravi Kumar. Design of fast dissolving tablets of chlorothalidone using novel coprocessed super disintegrant. J Chem Pharm Res 2010;2:671-9.

19. Rajni Bala, Shailesh Sharma. Formulation optimization and evaluation of fast dissolving film of aprepitant by using the design of the experiment. Faculty Pharm Cairo University 2018;56:159-68.

20. Pondugula Sudhakara Reddy, KV Ramana Murthy. Formulation and evaluation of oral fast dissolving films of poorly soluble drug ezetimibe using transcutol hp. Ind J Pharma Edu Res 2018;52:398-407.

21. Gupta M, Patel Mitul, Madhulika Kedawat. Enhancement of dissolution rate of rapidly dissolving oral film of meclizine hydrochloride by complexation of meclizine hydrochloride with a-cyclodextrine. J Appl Pharm Sci 2011;1:150-3. 